\title{
Nucleophosmin: from structure and function to disease development
}

\author{
Joseph K. Box, Nicolas Paquet*, Mark N. Adams, Didier Boucher, Emma Bolderson, Kenneth J. O’Byrne \\ and Derek J. Richard* (i)
}

\begin{abstract}
Nucleophosmin (NPM1) is a critical cellular protein that has been implicated in a number of pathways including mRNA transport, chromatin remodeling, apoptosis and genome stability. NPM1 function is a critical requirement for normal cellular biology as is underlined in cancer where NPM1 is commonly overexpressed, mutated, rearranged and sporadically deleted. Consistent with a multifunctional role within the cell, NPM1 can function not only as a protooncogene but also as a tumor suppressor. The aim of this review is to look at the less well-described role of NPM1 in the DNA repair pathways as well as the role of NPM1 in the regulation of apoptosis and its mutation in cancers.
\end{abstract}

Keywords: Nucleophosmin 1, DNA repair, Cancer, Apoptosis

\section{Background}

Nucleophosmin (NPM1), also known as B23, No38 or Numatrin, is an abundant nucleolar protein found in the nuclei of proliferating cells. NPM1 has been documented as participating in ribosome biogenesis, mRNA processing, chromatin remodeling, and embryogenesis (Fig. 1). While much is known about the function of NPM1 in metabolic pathways, it is becoming clear that NPM1 also has a critical function in maintaining genomic stability by functioning in various DNA repair pathways and regulating apoptosis. In this review, we shall present an updated overview of these roles, in particular the emerging data supporting a role for NPM1 in DNA repair. Lastly, we shall look at how NPM1 dysfunction contributes to cancer pathologies.

\section{Gene organization and evolutionary history}

Human NPM1 is located on chromosome $5 \mathrm{q} 35$ and is composed of 12 exons, encoding for at least two isoforms (Fig. 2a) [1]. NPM1.1 (or B23.1), corresponding to the full-length transcript, results in a 294 amino acids protein

\footnotetext{
*Correspondence: nicolas.paquet@qut.edu.au; derek.richard@qut.edu.au School of Biomedical Research, Institute of Health and Biomedical Innovation at the Translational Research Institute, Queensland University of Technology, Brisbane, QLD, Australia
}

(35-40 kDa) abundantly expressed in all tissues. Alternatively, NPM1.3 (also known as B23.2) results from the use of a distinct $3^{\prime}$ exon, and encodes for a protein expressed at low levels in cells, lacking the last 35 amino acids of the NPM1 C-terminus [2]. A third isoform NPM1.2 has been suggested, but so far, no biological data support this finding [3].

NPM1 belongs to a histone chaperones family, the Nucleophosmin/nucleoplasmin (NPM) family, a group that comprises multiple major functional members (NPM1, NPM2, NPM3 and the invertebrate NPM-like), and can be found amongst all Metazoan [4]. While this family is well characterized functionally, little is known about the evolution of these genes and proteins. At a glance, all members of the NPM family exhibit conserved structural motifs; a $\mathrm{N}$-terminal core domain, an acidic domain and a nuclear localization signal, associated with a less conserved, disorganized C-terminus region (Fig. 2b) [5]. Subsequently, crystallographic studies revealed a similar tertiary organization for NPM1 and NPM2 with monomers organized into pentameric donutshaped complexes [6, 7].

As simplified in Fig. 2c, phylogenetic analysis revealed the late emergence of the NPM1 monophyletic clade while, in contrast, NPM2 and NPM3 lineages appear of polyphyletic origin, with mammalians and amphibians 


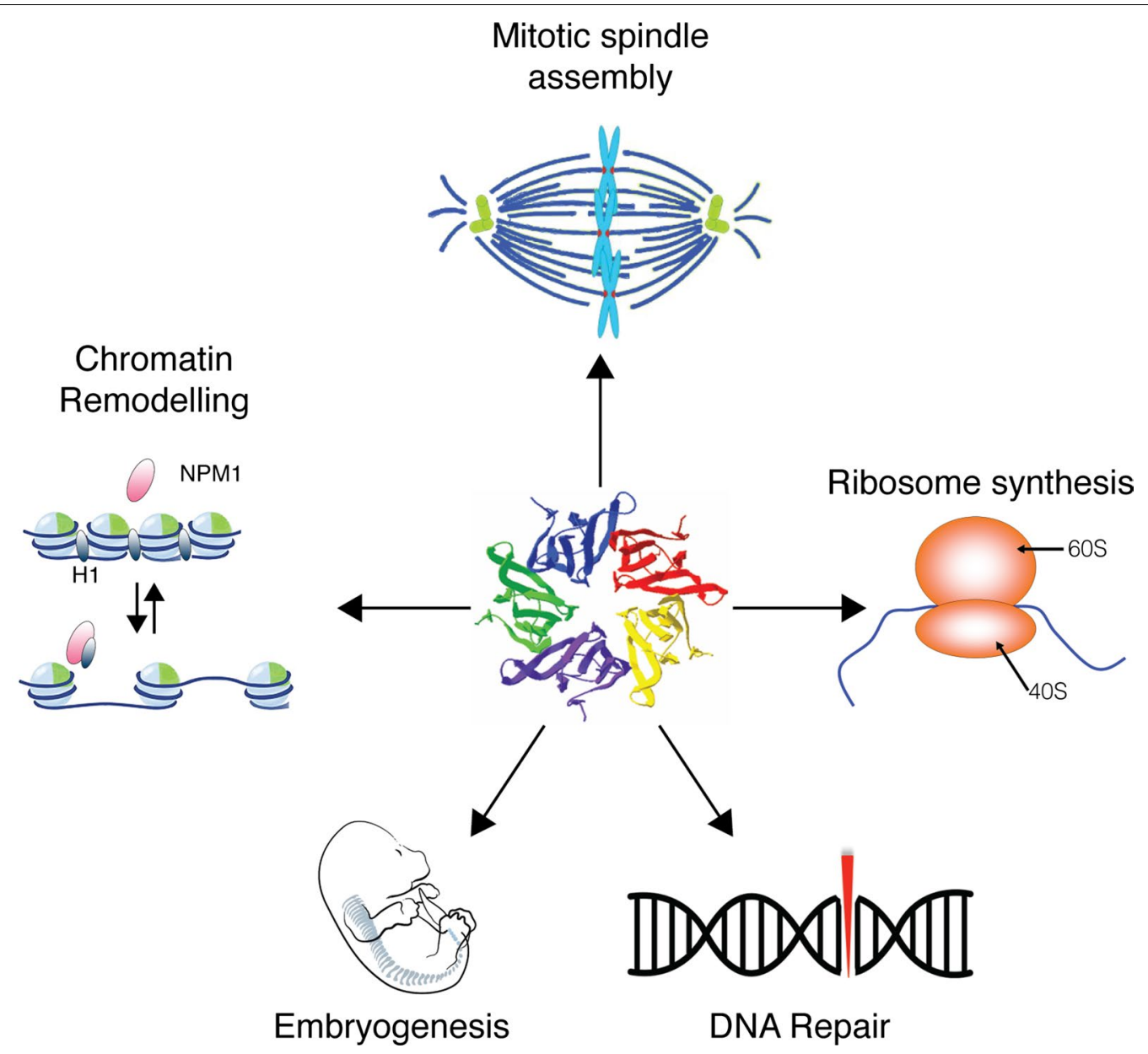

Fig. 1 Overview of NPM1 functions within cells. NPM1 participate to many biological processes such as DNA repair, embryogenesis, likely by interacting with the chromatin, by binding to histones and other chromatin remodeling proteins. Importantly, NPM1 also promotes ribosome biogenesis

sequences clearly differentiated [4]. Consistent with their shared expression profile, localization and direct physical interaction, NPM1 and NPM3 are the most closely related members of the family, suggesting functional constraints between the two proteins [4]. Huang et al. [8] further suggest that NPM3 may have evolved following the loss of a nucleic acid binding domain of NPM1, and functions as an element regulating NPM1 RNA binding.

Interestingly, codon usage within the NPM gene family indicates a strong purifying selection, materialized by a high rate of silent mutations which significantly deviates from neutrality. The highly conserved organization of NPM proteins as pentamers further supports the hypothesis of a strong negative selection operating at the structural level. Interestingly, potential sites of post-translational modifications are also selectively constrained, being conserved not only at the protein level but also showing a preferred codon usage [4]. Remarkably, these characteristics are shared with evolutionary features observed in histones, suggesting intertwined evolutionary history between the two families [9].

Despite being the most recent divergent NPM lineage, the functions of NPM1 are diverse and include roles in ribosome biogenesis [10, 11], mRNA processing [12], chromatin remodeling [13], embryogenesis [14], regulation of apoptosis and maintenance of genome stability.

\section{Characteristic structural features of nucleophosmin}

NPM1 structural architecture is well characterized by three distinct regions, onto which nucleolar and nuclear localization motifs, nucleic acids binding domains, oligomerization domains, histones binding regions, as well as a putative metal binding domain, have been mapped and described in detail [15-17] (Fig. 2a, b).

The N-terminal region is highly conserved in all members of the Nucleoplasmin/Nucleophosmin family and constitutes the core domain, which mediates NPM1 oligomerization and interactions with other proteins. 
a

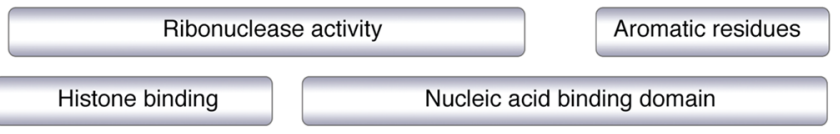

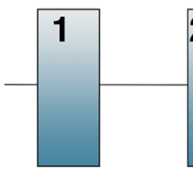

Ac. NES

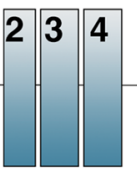

NES MB

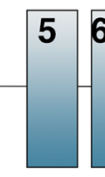

Ac. NLS b

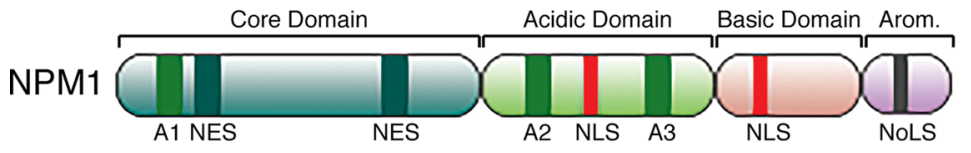

NPM2

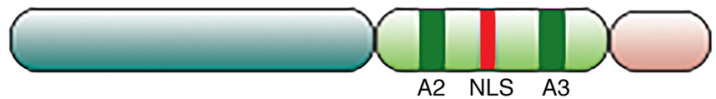

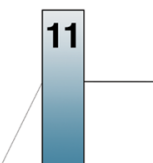

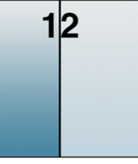

NPM1.1
NoLs

10

NPM1.3
C

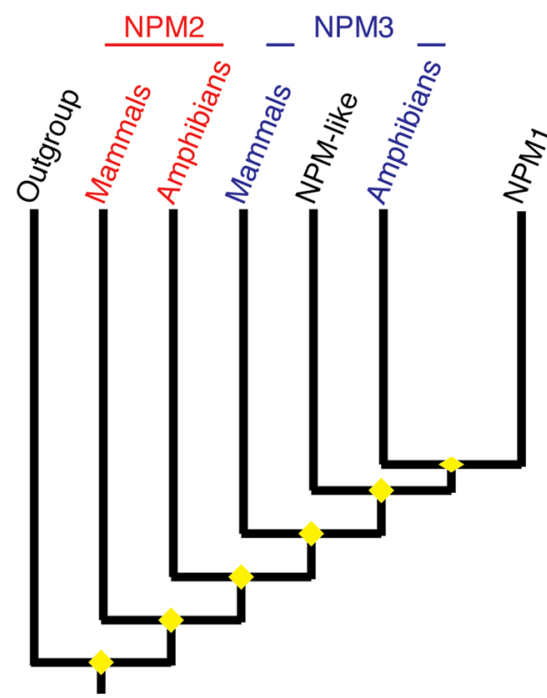

Fig. 2 a Superposition of NPM1 genomic structure and protein features. NPM1.1 and NPM1.3 are two splices variants resulting from the use of alternative codons. The two isoforms have different expression levels and localization. Ac Acidic domain, NES nuclear export signal, MB putative metal binding domain, NLS nucleus localization signal, NoLS Nucleolar localization signal. b Schematic structure of NPM proteins from human (not to scale). All proteins share a core, hydrophobic domain (b/ue) responsible for oligomerization and chaperone activity, followed by an acidic domain required for ribonuclease activity. A basic domain implicated in nucleic acid binding is common to NPM1 and NPM2, but absent in NPM3. Finally, only NPM1 exhibits a C-terminal aromatic stretch require for its nucleolar localization. In addition, NPM members harbor nuclear-localization signals (NLS), nucleolar-localization signal (NoLS), nuclear export signal (NES) and acidic clusters (a). c Simplified representation of the phylogenetic relationship within the NPM family. Inferred from [4]. The dendrogram reveals a clustering of sequences by type, rather than by species, and identifies NPM2 and NPM3 as polyphyletic groups

The three dimensional structure of the human NPM1core has been determined by X-ray crystallography and showed an organization into eight $\beta$-barrels forming a jelly roll barrel. Further, NPM1 monomers associate as donut-shaped homo-pentamers (Fig. 3a, b). The distribution of charges in this region is extremely asymmetric with negatively charged residues clustered on one side of the oligomer. Two pentamers of NPM1 interact in a head-to-head manner to form a decamer, and are arranged so that a monomer of the pentameric ring only contacts a single monomer of the other pentamer, allowing structural plasticity at the pentamer-pentamer interface [18]. This multimeric state is modulated by numerous post-translational modifications, especially phosphorylation events that regulate the monomerpentamer equilibrium by promoting the disassembly of 


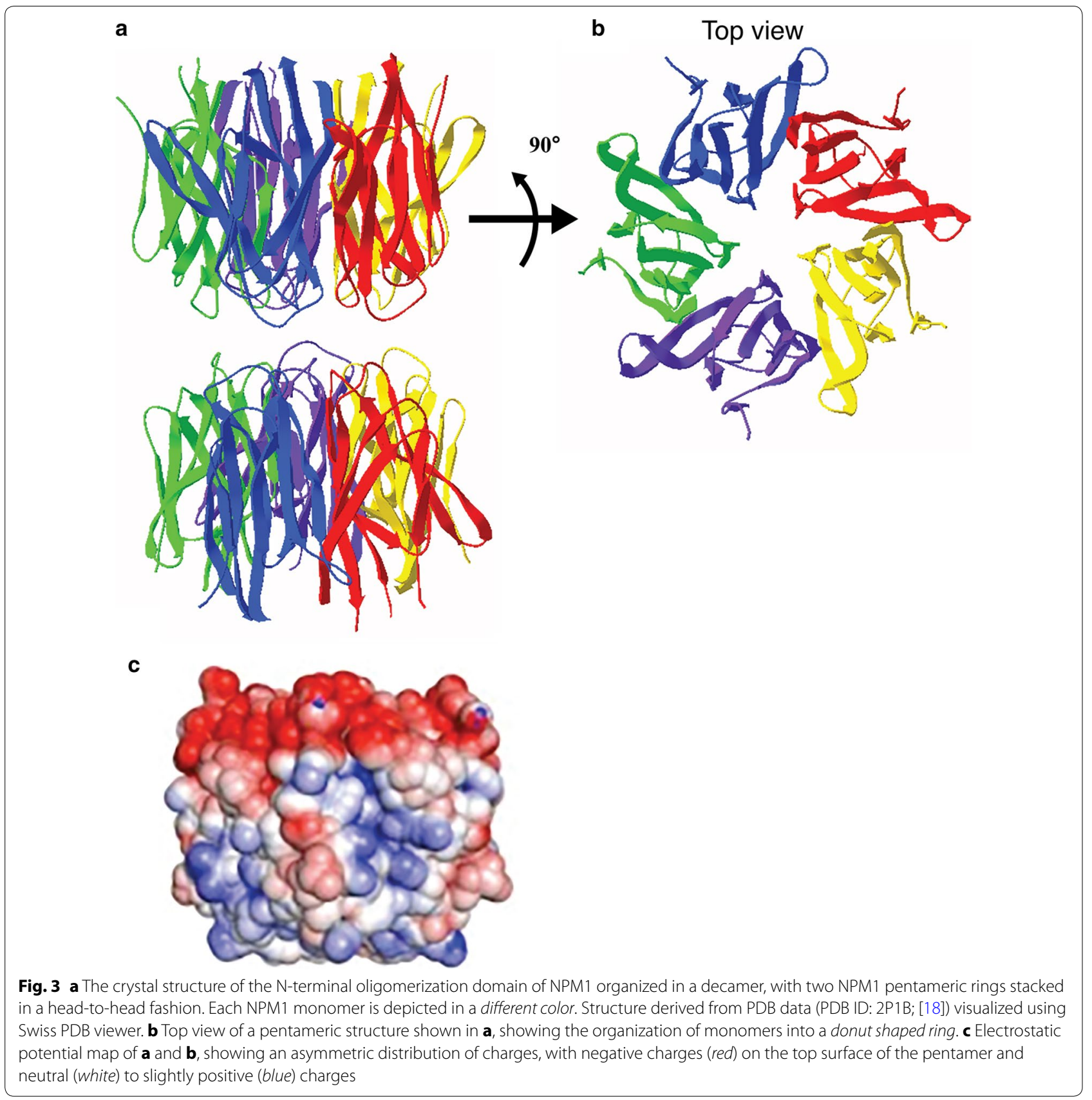

the pentamer into unstable, unfolded monomers. This structural polymorphism participates in the regulation of NPM1 localization and function [6]. As such, oligomerization of NPM1 has been linked to its nucleolar localization and role in cellular proliferation, while the monomeric form of NPM1 is associated with its role in the DNA damage response and induction of apoptosis [19].

The NPM1 central region appears unstructured and is marked by the presence of highly acidic regions composed of strings of aspartic and glutamic acids (A1, A2 and A3). They provide long tracks of negatively charged residues, known to be involved in the binding to Histones $\mathrm{H} 1, \mathrm{H} 3, \mathrm{H} 4, \mathrm{H} 2 \mathrm{~A}$ and $\mathrm{H} 2 \mathrm{~B}$, potentially by mimicking the charges of DNA and RNA [20, 21]. It also contains a nuclear localization signal.

The C-terminus of NPM1 is characterized by the presence of a basic, positively charged cluster of amino acids, immediately followed by a stretch of aromatic residues, providing an adequate platform allowing the binding 
to nucleic acids and ATP $[16,22]$. These aromatic residues constitute an atypical nucleolar localization signal (NoLS), and their mutation are responsible for the unfolding and the aberrant NPM1 localization typical in acute myeloid leukemia (AML) cases.

\section{Function of NPM1 in apoptosis}

Although the best described function of NPM1 is in ribosome biogenesis, NPM1 also displays a critical role in regulating apoptosis. NPM1 expression levels have been implicated in controlling the cellular apoptotic response. In a variety of cell based models, several studies have demonstrated that down-regulation of NPM1 sensitizes cells to apoptosis, while increased levels of the protein protects against apoptosis [23-25]. In a disease setting, the balance between NPM1 expression and cell fate is demonstrated in hypoxia-driven cancers. For example, suppression of hypoxia-induced NPM1 expression promotes apoptosis whereas overexpression protects from hypoxia-mediated cell death [26]. From a cancer perspective, elevated levels of NPM1 might promote malignant transformation by enabling cell survival.

Several proteins have been identified that impact cell survival by interacting with and regulating NPM1 protein levels. In the nucleolus, the tumor suppressor p14 ${ }^{\mathrm{ARF}}$ interacts with NPM1 to promote degradation of the protein and induce cell death (Fig. 4) [27]. However, the interplay between NPM1 and $\mathrm{p} 14^{\mathrm{ARF}}$ is more complex, with NPM1 also acting as major cellular reservoir of p14 ${ }^{\text {ARF }}$ (Fig. 4). After various stimuli NPM1 releases p14 ${ }^{\mathrm{ARF}}$ allowing binding to MDM2 and preventing the proteasomal degradation of p53 (Fig. 4) [28]. Consistently, depletion of NPM1 with siRNA results in increased apoptosis due to a greater amount of free $\mathrm{p} 14^{\mathrm{ARF}}[28]$. On the contrary, up-regulation of NPM1 appears to antagonize $\mathrm{p} 14^{\mathrm{ARF}}$ and increases its nucleolar retention [29]. These observations provide evidence that NPM1 regulates cell fate in a p53-dependent manner by directing p14 ${ }^{\mathrm{ARF}}$ to nucleoli and preventing inhibition of MDM2 (Fig. 4) [27, 30, 31]. Other studies have also linked NPM1 with the tumor suppressor activity of p53. For example, NPM1 is also able to interact directly with MDM2, independently of $\mathrm{p} 14^{\mathrm{ARF}}$, and act as a p53:MDM2 inhibitor to protect p53 from degradation (Fig. 4) [32, 33]. Interestingly, NPM1 is also reported to directly associate with p53 [34]. However, this interaction remains contentious as an inability for NPM1 to interact with p53 has also been reported [27]. It may be that an interaction between NPM1 and p53 might only occur in certain cellular contexts. Nonetheless, this observation requires clarification.

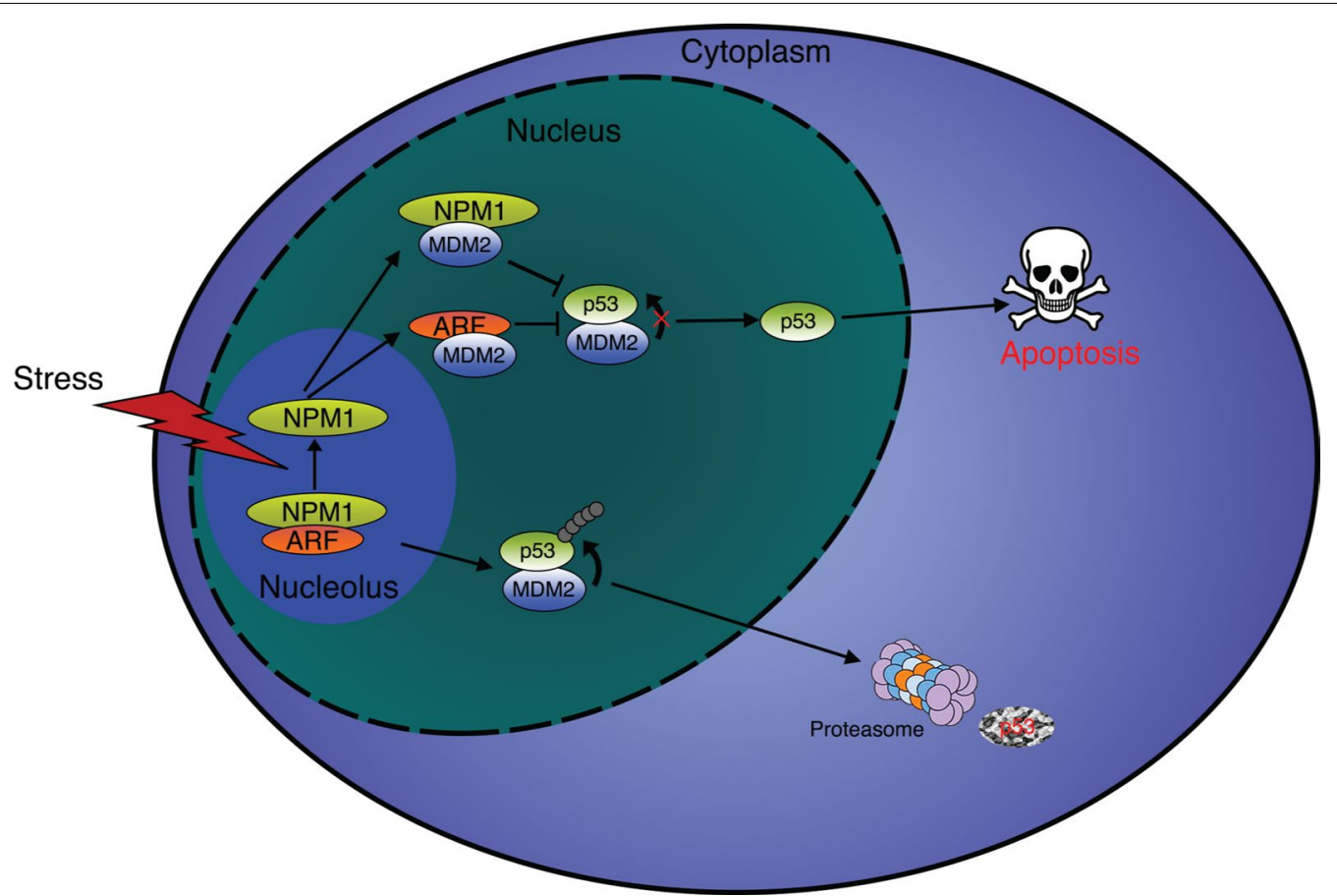

Fig. 4 Regulation of apoptosis by NPM1. In unstressed cells, p14 ${ }^{\text {ARF }}$ and NPM1 form a dimer in the nucleoli, allowing MDM2 to target p53 for proteasomal degradation. Following a stress, such as DNA damages, p14 ARF and NPM1 dissociate and relocate to the nucleus were they sequester MDM2, leading to the stabilization and activation of p53. p53 then induces the transcription of various genes involved in cell-cycle arrest, DNA repair and apoptosis 
In addition to $\mathrm{p} 14^{\mathrm{ARF}}$, MDM2 and possibly p53, NPM1 has been reported to bind $\mathrm{PKB} / \mathrm{Akt}$ in order to modulate cell survival. In the nucleus, Akt binds NPM1 in response to growth factor stimulation to protect NPM1 against caspase-3-mediated proteolytic degradation and promote cell survival [35]. Similarly, NPM1 stability is enhanced by interacting with erythroid differentiation-associated gene (EDAG), promoting acute myeloid leukemia (AML) cell survival [36]. In another instance, the interaction of GAGE with NPM1 also enables NPM1 stability to promote resistance to interferon- $\gamma$-induced apoptosis [37].

NPM1 has also been portrayed as regulating cell fate by modulating both the intrinsic and extrinsic apoptosis pathways. During the intrinsic apoptotic response, p53 is required in the mitochondrial to enable cytochrome $\mathrm{C}$ release. Overexpression of NPM1 prevents the translocation of p53 from the nucleus to the mitochondria [38], suggesting that NPM1 may protect cells from apoptosis by reducing the mitochondrial level of p53. In acute promyelocytic leukemia cells expressing the NPM1retinoic acid receptor $\alpha$ (NPM1-RAR) fusion protein, NPM1-RAR blocked TNF-induced extrinsic apoptosis by inhibiting signaling to activate caspase- 3 and -8 [39]. Similarly, mutant forms of NPM1 are indicated to impede apoptosis by directly inhibiting the proteolytic function of caspase- 6 and -8 in the cytoplasm [40]. Interestingly, in anaplastic large-cell lymphoma cells, the cytoplasmic fraction of the NPM1-ALK fusion protein is solely responsible for inducing apoptosis by engaging the DNAdamage response [41]. These studies suggest, at least for the mutant or NPM1 fusion proteins, that the cytoplasmic fraction of NPM1 may be required to regulate the apoptotic pathways.

\section{Role of NPM1 in the DNA repair response}

Loss of NPM1 function has been shown to be associated with increased genome instability [42]. Several studies have demonstrated the critical role of NPM1 in the maintenance of genome stability through its interaction with unduplicated centrosomes [42]. The phosphorylation of NPM1 by CDK2/Cyclin E promotes the release of NPM1 from the centrosome during duplication; this represents an essential step for duplication to occur. However, during mitosis NPM1 re-associates with the centrosomes at the spindle bodies and appears to be controlling centrosome duplication [43]. Indeed, depletion of NPM1 has been shown to promote genome instability (unaligned chromosomes, micronuclei) $[44,45]$. In mice, the chromosomal instability associated with NPM1 depletion partially explains the embryonic lethality [14].

However, it has only recently become clear that NPM1 is likely to have a direct role in the repair of DNA lesions. Multiple DNA repair pathways promote the repair of different DNA lesions and NPM1 has been implicated in several of these repair pathways (Fig. 5).

DNA double-strand breaks (DSB) are the most destructive and genotoxic lesions encountered by cells and as such complex cascades have evolved to sense, signal and repair these breaks. DNA DSBs can then be repaired by two pathways, homologous recombination (HR) and non-homologous end-joining (NHEJ) (reviewed in [46]). HR utilizes a sister chromatid as a template for repair and therefore can only be performed in the late S-phase and G2 phases of the cell cycle. In contrast, NHEJ can occur in any phase of the cell cycle and involves a less complex method of ligating the two DNA ends together. As overhanging DNA may be resected during this method, NHEJ is generally known as the more error-prone mechanism of DNA DSB repair. In the HR process, DSBs are detected and signaling pathways are initiated by the ATM/ATR kinases, promoting the recruitment of repair proteins, including nucleases that resect DNA with a $5^{\prime}-3^{\prime}$ polarity. This resection generates stretches of single stranded DNA, which invade into a sister chromatid, allowing it to act as a template for polymerase-mediated extension of the invading strand. Following this extension and re-ligation of DNA strands this reaction then yields two intact and identical DNA molecules [47].

Thus far, NPM1 has only been implicated in homologous recombination (HR). Following DNA double-strand break induction, NPM1 is recruited from the nucleolus into the nucleoplasm and binds to the chromatin [48]. NPM1 is phosphorylated at Threonine 199 by the cyclin-dependent kinases CDK1 and CDK2 during the cell cycle [49]. A subsequent study showed that following induction of DNA double-strand breaks by ionizing irradiation, NPM1 phosphorylated on threonine 199 localizes to sites of DNA double-strand breaks, colocalizing with other DNA repair proteins such as $\gamma \mathrm{H} 2 \mathrm{AX}$ and BRCA1 [50]. Phosphorylated NPM1 is recruited to sites of DNA marked by K63-linked ubiquitin conjugates in a process dependent upon the ubiquitin ligases RNF8 and RNF168. Depletion of NPM1 or expression of nonphosphorylatable NPM1 (T199A) leads to persistence of Rad51 foci suggesting that repair of DNA DSBs is not completed. This is further supported by the detection of increased DNA lesions in cells expressing NPM1 T199A. In contrast, cellular survival following ionizing radiation was not significantly affected [19]. Another study also analyzed $\gamma \mathrm{H} 2 \mathrm{AX}$ and Rad51 foci kinetics and showed that DNA damage also persisted in NPM1-null mouse embryonic fibroblast (MEF) cells [51]. Like the studies in human cells, NPM1-null MEFs also exhibited increased DNA lesions and a modest decrease in cellular survival following ionizing radiation. An anti-cancer agent, YTR107, was also shown to act by binding to NPM1 and 


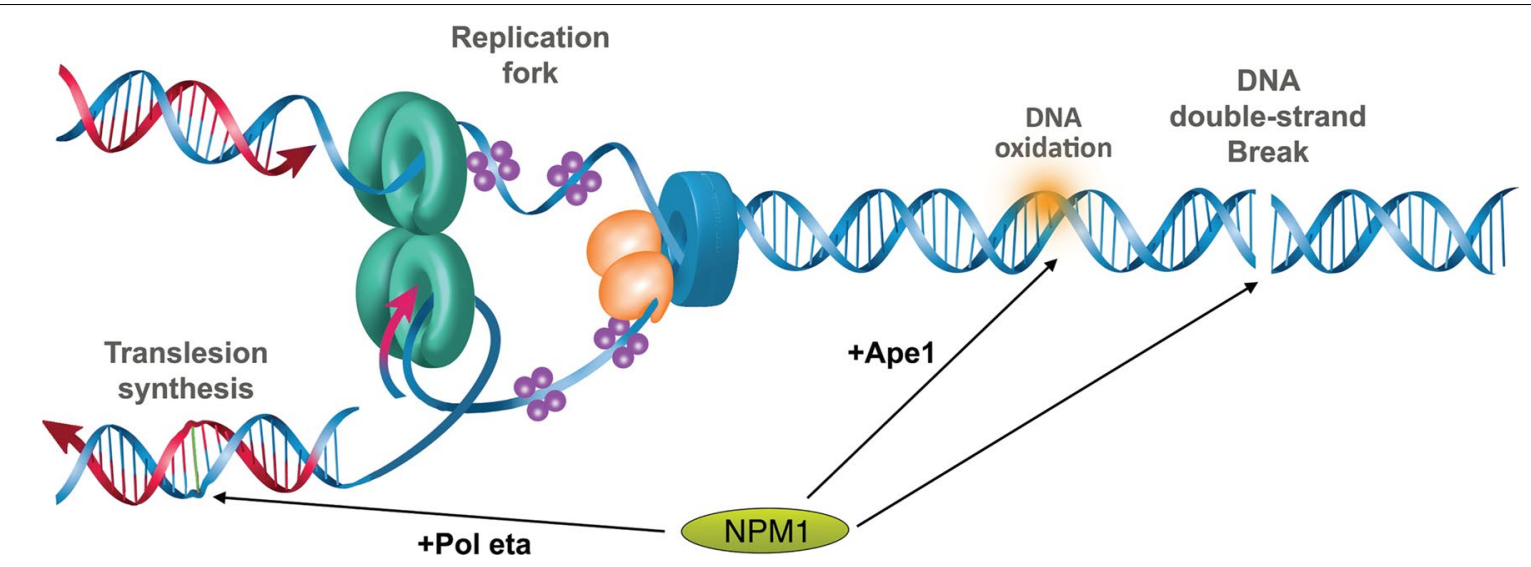

Fig. 5 Overview of NPM1 functions in various DNA damage response pathways. NPM1 has been shown to modulate the BER pathway as well as the translesion synthesis by modulating the levels of apurinic/apyrimidinic endonuclease 1 (APE1) and polymerase eta. In the absence of NPM1 or with the expression of non-phosphorylatable NPM1, double-strand break repair by homologous recombination fails to be completed, however the exact mechanism of NPM1 function in these pathway remain to be fully elucidated

altering its function. YTR107 inhibits DNA repair and radiosensitizes cells in an NPM1-dependent process [51]. In light of the above it is clear that NPM1 has a role in DNA DSB repair, however much is still to be elucidated about the exact mechanism of its function in these pathways (Fig. 5).

Following exposure of cells to agents such as UV, DNA lesions may cause replication forks to stall as the replicative polymerases are unable to bypass the UV-induced bulky lesions. In order for these stalled replication forks to be restarted, they can be repaired by a form of HR or be bypassed in a mechanism known as translesion synthesis (TLS, reviewed in [52], Fig. 5). A recent study identified NPM1 as a key player of the TLS pathway [53]. This process enables switching of the DNA polymerase to a low fidelity DNA polymerase that can replicate the DNA across the lesion. NPM1 regulates TLS by binding to and protecting DNA Polymerase Eta (POLH, poln) from proteosomal degradation promoting its role in TLS. The mutated NPM1 (NPM1c+, found in $30 \%$ of AML cases) was found to result in increased degradation of poln, perhaps explaining the improved prognosis in AML patients with NPM1 mutations [53].

In addition to its role in DNA double-strand break repair and translesion synthesis, NPM1 has also been shown to respond to DNA lesions induced by UV light. The alterations to nucleotides caused by UV irradiation are repaired by the nucleotide excision repair pathway, a process that is dependent upon the PCNA homo-trimer (reviewed in [54]). The levels of NPM1 protein were shown to increase following cellular exposure to UV [55]. Exogenous overexpression of NPM1 was also found to increase cellular survival and DNA repair capacity following UV irradiation. Supporting a role for NPM1 in nucleotide excision repair (NER), it was found to transcriptionally regulate the crucial NER protein PCNA [55]. Following UV irradiation, dephosphorylation of NPM1 on Threonine 199, 234 and 237 residues occurs in a PP1 $\beta$-dependent manner. Dephosphorylation of these sites on NPM1 enhances the interaction between NPM1 and the retinoblastoma tumor suppressor protein (pRB), which then allows the release of E2F1 from pRB. E2F1 subsequently functions to transcriptionally activate several downstream DNA repair genes, including XPC, DDB2 and RPA14, facilitating DNA repair [56].

Oxidative damage to DNA is caused predominantly by normal cellular metabolism and is repaired by the base excision repair pathway (BER reviewed in [57]). NPM1 has been shown to modulate the BER pathway through control of the apurinic/apyrimidinic endonuclease 1 (APE1) protein levels and modulation of the AP-site incision activity of APE1, which is required for base excision repair (Fig. 5) [58-60]. Several nucleolar proteins involved in BER were also mislocalised in NPM1-deficient cells, including APE1, Fen1 and LigI [61]. NPM1 was also found to belong to a complex containing several BER proteins, including APE1, Fen1, Pol $\beta$ and LigI [62, 63].

\section{NPM1 and cancer}

As discussed above, NPM1 is involved in maintaining genome stability and regulating apoptosis, and, as such, has been described as having both oncogenic and tumor suppressive functions. NPM1 was first associated with cancer where approximately one-third of anaplastic large-cell non-Hodgkin's lymphomas were found to 
express a fusion between NPM1 and the catalytic domain of anaplastic lymphoma receptor tyrosine kinase (ALK) [64]. In addition, $35 \%$ of all AML patients $(50-60 \%$ in adults with normal karyotype) show NPM1 rearrangements or mutations [65], leading the World Health Organization to introduce mutated NPM1 as an AML entity [66]. All NPM1 mutations reported occur with the C-terminus of the protein altering either the folding of this region or the Nucleolar localization signal itself. Named NPM1 Cytoplasm positive or NPM1c+, these mutations result in cytoplasmic localization of the protein, and act as dominant negative by retaining WT NPM1 in the cytoplasm (Fig. 6b) [67].

Patients with NPM1 mutations proved to have a better outcome with increased complete remission and improved overall survival [68]. However, within this group of patients, the antigen expression pattern of HLADR $(+)$ CD34(+) CD7(+) is associated with poor prognosis [69]. NPM1c+ has been shown to result in microRNAs deregulation [70], and a recent in vitro study established that NPM1c+ could enhance leukemia cells adhesion, migratory and invasive potential through MEK/ERK activation

a

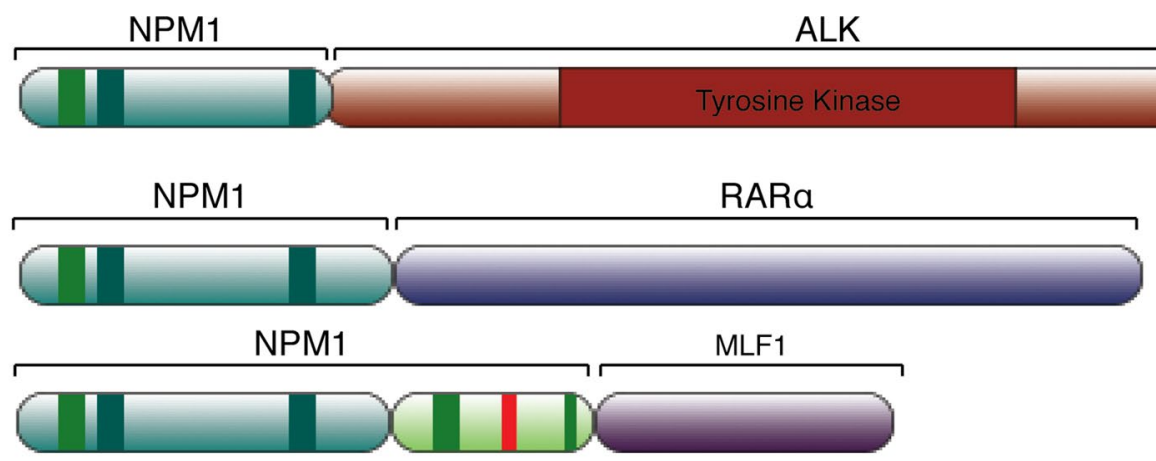

b

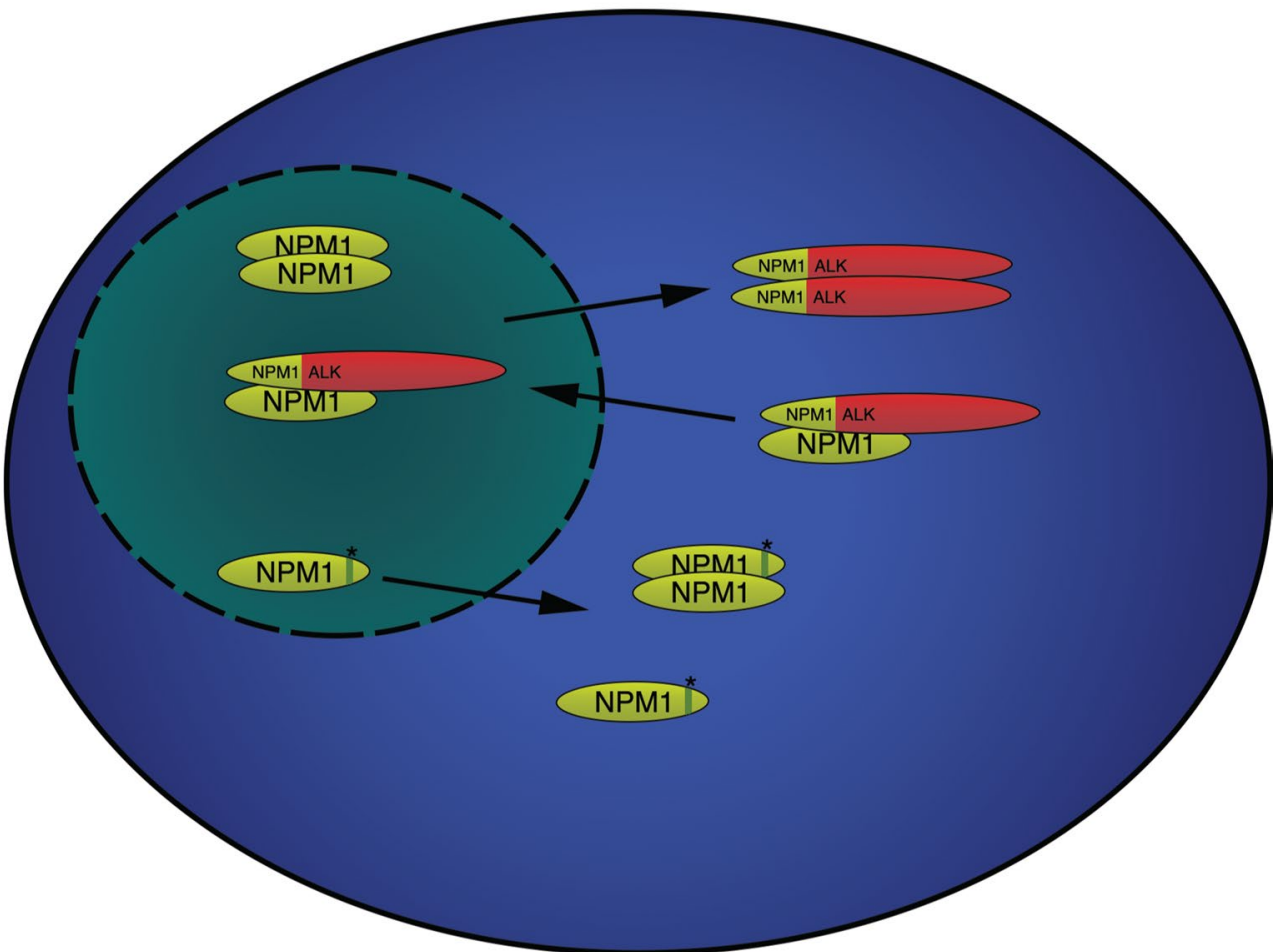

Fig. 6 a Schematic structure of NPM1 chimeric proteins found in cancers. NPM1 is represented as in Fig. 2b. b Representation of the localization of wild-type NPM1, NPM1c+ and NPM1-ALK fusion protein in cancer. NPM1c+ (indicated by an asterisk) is cytoplasmic and can form dimers with NPM1 WT, retaining it in the cytoplasm. NPM1-ALK can dimerize and localize to the cytoplasm. Inversely, NPM1-ALK can form heterodimers with NPM1 WT, causing ALK dislocation into the nucleus (arrow). These cells shown both aberrant localization of ALK in the nucleus, and NPM1 in the cytoplasm 
[71]. Notably, NPM1 mutation in a knock-in mouse model resulted in AML initiation [72, 73], and studies on MEFs have shown that NPM1 mutation results in p14 ${ }^{\mathrm{ARF}}$ destabilization [74] and c-Myc stabilization [75].

In anaplastic large-cell lymphoma (ALCL), NPM1 fusion with anaplastic lymphoma receptor tyrosine kinase (ALK) can be found in $85 \%$ of the ALK+ ALCL, this results in the expression of a chimeric oncogenic protein formed by the C-terminus of NPM1 and the kinase domain of ALK (Fig. 6a) [64, 76]. In these cells both NPM1 and ALK exhibits aberrant localization. Further, dimerization of NPM1-ALK leads to a constitutive activation of the ALK kinase (Fig. 6b) [76].

Chimeric proteins between NPM1 and the retinoic acid receptor- $\alpha$ gene (RAR $\alpha$ ) or between NPM1 and the myelodysplasia/myeloid leukemia factor 1 (MLF1) have also been reported in rare cases of leukemia (Fig. 6a) [77, 78].

Besides leukemia, involvement of NPM1 has also been reported in several solid cancers. Overall, NPM1 overexpression is linked to high grade tumors and poor prognosis, as observed in brain glioblastoma [79], oral squamous cell carcinoma [80], non-small cells lung cancer (NSCLC) [51], hepatocellular carcinomas (HCC) [81], colon cancer [82-84], ovarian cancer $[62,85]$, and endometrial carcinoma [86]. A higher level of NPM1 has also been observed in prostate cancer, when compared to normal tissue $[87,88]$, promoting cells growth and invasiveness [89]. In bladder cancer, high levels of NPM1are not associated with tumor grade, but with cancer progression, recurrence, and poor prognosis [90]. NPM1 overexpression has also been reported in thyroid cancer [91], with thyroid cancer cell lines showing NPM1 mislocalization in the absence of the mutations observed in AML patients [92].

However, low levels of NPM1 have also been observed in some cancers, such as gastric cancers (mRNA and protein) compared to normal tissue [93]. In breast cancer, low NPM1 levels are also associated with poor outcome, independently of the molecular subtype, with granular staining of NPM1 correlating with poor prognosis [94].

Since NPM1 is overexpressed in many types of cancer and because of its role in genome stability, it could be a potential target for new cancer therapy strategies. Different molecules have been trialed to induce cell death by destabilizing NPM1 [95-98] or inhibiting its interaction with other DNA repair proteins [99]. Recent studies have focused on combining NPM1 inhibition with a DNA damaging agent, for instance ionizing radiation $[51,100]$, or a cytotoxic drug [101]. Other strategies are aiming specifically at NPM1c+ itself [102], or in combination with damage induction by increasing oxidative stress in cells [103-106].

\section{Frontiers}

As summarized here, NPM1 plays multiple roles within human cells while the best documented is in RNA transport and ribosome biogenesis, it is clear that NPM1 also plays a critical role in the regulation of apoptosis and in the maintenance of genomic homeostasis.

Genome instability is one of the underlying causes of cellular transformation and cancer development. Once a cancer does form, genome instability becomes a common feature seen as a universal hallmark of all cancers [107]. This instability provides the cancer the ability to evolve and adapt to the environment in which it is located; further, defects in the apoptosis pathways allow the cancer cell to cope and survive with levels of genetic instability that would normally induce cell death.

Given the critical role NPM1 plays in genome stability and apoptosis it is hardly surprising that NPM1 dysfunction is a frequent feature in cancers. Indeed, as evidence of NPM1 function in DNA repair pathways increases, it explains at least in part the genetic instability associated with cancers such as AML. Further, NPM1 deregulation or mutation will suppress the ability of that cell to respond to apoptotic stimuli, allowing for the tolerance of the genetic instability. Consistent with a role in genetic instability and specifically the repair of double-strand DNA breaks we see that AML patients with a mutated NPM1 have a $>2$ fold higher odds of achieving complete remission as compared to patients with a wild type NPM1 [108]. NPM1 in cancer is most strikingly highlighted in acute myeloid leukemia where approximately $30 \%$ of patients will have a mutation or fusion event implicating NPM1.

Despite the importance of NPM1 in genome stability it is clear that we do not fully understand how NPM1 functions in the repair of DNA damage. We know that NPM1 moves to sites of double-strand DNA breaks within the genome, but we do not yet understand how NPM1 functions at those break sites. We do not know if NPM1 binds to nucleic acids at those sites or if it is involved in remodeling chromatin. It is clear, however, that understanding how NPM1 participates in DNA repair and genome stability will help to delineate the role of NPM1 in both normal and cancerous cells. This will perhaps provide insights into why NPM1 dysfunction is a marker of drug and radiation sensitivities.

\section{Abbreviations}

AKT: protein kinase B; ALK: anaplastic lymphoma receptor tyrosine kinase; AML: acute myeloid leukemia; APE1: apurinic/apyrimidinic endonuclease 1; ATM: ataxia telangiectasia mutated protein; ATP: adenosine triphosphate; ATR: ataxia telangiectasia and Rad3 related protein; BRCA1: breast cancer 1; CDK: cyclin-dependent kinase; DDB2: damage-specific DNA binding protein 2; DNA: deoxyribonucleic acid; DSB: double-strand breaks; E2F1: E2F transcription factor 1; EDAG: erythroid differentiation-associated gene; HR: homologous recombination; kDa: kilo dalton; MDM2: mouse double minute 
2 homolog; MEF: mouse embryonic fibroblast; MLF1: myelodysplasia/myeloid leukemia factor 1; mRNA: messenger RNA; NER: nucleotide excision repair; NHEJ: non-homologous end-joining; NoLS: nucleolar localisation signal; NPM1: nucleophosmin1; PCNA: proliferating cell nuclear antigen; PKB: protein kinase $B$; RAR: retinoic acid receptor a; RNA: ribonucleic acid; RNF: ring finger protein 1; RPA: replication protein $A ;$ TLS: translesion DNA synthesis; TNF: tumor necrosis factor; UV: ultra violet; XPC: xeroderma pigmentosum, complementation group $C$.

\section{Authors' contributions}

$J K B, N P, M N A, D B, E B, K J O$ and DJR wrote the manuscript. All authors read and approved the final manuscript.

\section{Competing interests}

The authors declare that they have no competing interests.

\section{Funding information}

This work was supported by a NHMRC project Grant (1066550), an ARC project Grant (D.J.R, DP 120103099) and by a Queensland Health Senior Clinical Research Fellowship (K.J.O.). M.A. holds a NHMRC Early Career Fellowship (1091589). E.B. is supported by an Advance Queensland Research Fellowship.

Received: 8 May 2016 Accepted: 16 August 2016

Published online: 24 August 2016

\section{References}

1. Umekawa H, Chang JH, Correia JJ, Wang D, Wingfield PT, Olson MO. Nucleolar protein B23: bacterial expression, purification, oligomerization and secondary structures of two isoforms. Cell Mol Biol Res. 1993;39(7):635-45.

2. Dalenc F, Drouet J, Ader I, Delmas C, Rochaix P, Favre G, Cohen-Jonathan $\mathrm{E}$, Toulas $\mathrm{C}$. Increased expression of a $\mathrm{COOH}$-truncated nucleophosmin resulting from alternative splicing is associated with cellular resistance to ionizing radiation in HeLa cells. Int J Cancer. 2002;100(6):662-8.

3. Lim MJ, Wang XW. Nucleophosmin and human cancer. Cancer Detect Prev. 2006;30(6):481-90.

4. Eirin-Lopez JM, Frehlick LJ, Ausio J. Long-term evolution and functional diversification in the members of the nucleophosmin/nucleoplasmin family of nuclear chaperones. Genetics. 2006;173(4):1835-50.

5. Frehlick LJ, Eirin-Lopez JM, Ausio J. New insights into the nucleophosmin/nucleoplasmin family of nuclear chaperones. BioEssays. 2007;29(1):49-59

6. Mitrea DM, Grace CR, Buljan M, Yun MK, Pytel NJ, Satumba J, Nourse A, Park CG, Madan Babu M, White SW, et al. Structural polymorphism in the N-terminal oligomerization domain of NPM1. Proc Natl Acad Sci USA. 2014;111(12):4466-71.

7. Platonova O, Akey IV, Head JF, Akey CW. Crystal structure and function of human nucleoplasmin (npm2): a histone chaperone in oocytes and embryos. Biochemistry. 2011;50(37):8078-89.

8. Huang N, Negi S, Szebeni A, Olson MO. Protein NPM3 interacts with the multifunctional nucleolar protein B23/nucleophosmin and inhibits ribosome biogenesis. J Biol Chem. 2005;280(7):5496-502.

9. Eirin-Lopez JM, Gonzalez-Romero R, Dryhurst D, Mendez J, Ausio J. Long-term evolution of histone families: old notions and new insights into their mechanisms of diversification across eukaryotes. In: Pontarotti P, editor. Evolutionary biology: concept, modeling and application. Berlin: Springer-Verlag; 2009. p. 139-62.

10. Yu Y, Maggi LB Jr, Brady SN, Apicelli AJ, Dai MS, Lu H, Weber JD. Nucleophosmin is essential for ribosomal protein $L 5$ nuclear export. Mol Cell Biol. 2006;26(10):3798-809.

11. Savkur RS, Olson MO. Preferential cleavage in pre-ribosomal RNA byprotein B23 endoribonuclease. Nucleic Acids Res. 1998;26(19):4508-15.

12. Murano K, Okuwaki M, Hisaoka M, Nagata K. Transcription regulation of the rRNA gene by a multifunctional nucleolar protein, B23/ nucleophosmin, through its histone chaperone activity. Mol Cell Biol. 2008:28(10):3114-26.
13. Okuwaki M, Matsumoto K, Tsujimoto M, Nagata K. Function of nucleophosmin/B23, a nucleolar acidic protein, as a histone chaperone. FEBS Lett. 2001;506(3):272-6.

14. Grisendi S, Bernardi R, Rossi M, Cheng K, Khandker L, Manova K, Pandolfi PP. Role of nucleophosmin in embryonic development and tumorigenesis. Nature. 2005;437(7055):147-53.

15. Okuwaki M. The structure and functions of NPM1/nucleophosmin/B23, a multifunctional nucleolar acidic protein. J Biochem. 2008;143(4):441-8.

16. Hingorani $K$, Szebeni A, Olson MO. Mapping the functional domains of nucleolar protein B23. J Biol Chem. 2000;275(32):24451-7.

17. Chan WY, Liu QR, Borjigin J, Busch H, Rennert OM, Tease LA, Chan PK. Characterization of the cDNA encoding human nucleophosmin and studies of its role in normal and abnormal growth. Biochemistry. 1989:28(3):1033-9.

18. Lee HH, Kim HS, Kang JY, Lee BI, Ha JY, Yoon HJ, Lim SO, Jung G, Suh SW. Crystal structure of human nucleophosmin-core reveals plasticity of the pentamer-pentamer interface. Proteins. 2007;69(3):672-8.

19. Koike A, Nishikawa H, Wu W, Okada Y, Venkitaraman AR, Ohta T. Recruitment of phosphorylated NPM1 to sites of DNA damage through RNF8dependent ubiquitin conjugates. Cancer Res. 2010;70(17):6746-56.

20. Gadad SS, Senapati P, Syed SH, Rajan RE, Shandilya J, Swaminathan V, Chatterjee S, Colombo E, Dimitrov S, Pelicci PG, et al. The multifunctional protein nucleophosmin (NPM1) is a human linker histone $\mathrm{H} 1$ chaperone. Biochemistry. 2011;50(14):2780-9.

21. Swaminathan V, Kishore AH, Febitha KK, Kundu TK. Human histone chaperone nucleophosmin enhances acetylation-dependent chromatin transcription. Mol Cell Biol. 2005;25(17):7534-45.

22. Choi JW, Lee SB, Kim CK, Lee KH, Cho SW, Ahn JY. Lysine 263 residue of NPM/B23 is essential for regulating ATP binding and B23 stability. FEBS Lett. 2008;582(7):1073-80.

23. Ahn JY, Liu X, Cheng D, Peng J, Chan PK, Wade PA, Ye K. Nucleophosmin/B23, a nuclear PI $(3,4,5) \mathrm{P}(3)$ receptor, mediates the antiapoptotic actions of NGF by inhibiting CAD. Mol Cell. 2005;18(4):435-45.

24. Wu MH, Chang JH, Yung BY. Resistance to UV-induced cell-killing in nucleophosmin/B23 over-expressed NIH 3T3 fibroblasts: enhancement of DNA repair and up-regulation of PCNA in association with nucleophosmin/B23 over-expression. Carcinogenesis. 2002;23(1):93-100.

25. Wu MH, Chang JH, Chou CC, Yung BY. Involvement of nucleophos$\mathrm{min} / \mathrm{B} 23$ in the response of HeLa cells to UV irradiation. Int J Cancer. 2002:97(3):297-305.

26. Li J, Zhang X, Sejas DP, Bagby GC, Pang Q. Hypoxia-induced nucleophosmin protects cell death through inhibition of p53. J Biol Chem. 2004;279(40):41275-9.

27. Itahana KBK, Jin A, Itahana Y, Hawke D, Kobayashi R, Zhang Y. Tumor suppressor ARF degrades B23, a nucleolar protein involved in ribosome biogenesis and cell proliferation. Mol Cell. 2003;12(5):1151-64.

28. Qin FX, Shao HY, Chen XC, Tan S, Zhang HJ, Milao ZY, Wang L, Hui-Chen, Zhang L. Knockdown of NPM1 by RNA interference inhibits cells proliferation and induces apoptosis in leukemic cell line. Int J Med Sci. 2011;8(4):287-94.

29. Korgaonkar C, Hagen J, Tompkins V, Frazier AA, Allamargot C, Quelle FW Quelle DE. Nucleophosmin (B23) targets ARF to nucleoli and inhibits its function. Mol Cell Biol. 2005;25(4):1258-71.

30. Korgaonkar CHJ, Tompkins V, Frazier AA, Allamargot C, Quelle FW, Quelle DE. Nucleophosmin (B23) targets ARF to nucleoli and inhibits its function. Mol Biol Cell. 2005;25(4):1258-71.

31. Ye K. Nucleophosmin/B23, a multifunctional protein that can regulate apoptosis. Cancer Biol Ther. 2005;4(9):918-23.

32. Kurki SPK, Latonen L, Kiviharju TM, Ojala PM, Meek D, Laiho M. Nucleolar protein NPM interacts with HDM2 and protects tumor suppressor protein p53 from HDM2-mediated degradation. Cancer Cell. 2004;5(5):465-75.

33. Jin AIK, O'Keefe K, Zhang Y. Inhibition of HDM2 and activation of p53 by ribosomal protein L23. Mol Cell Biol. 2004;24(17):7669-80.

34. Colombo E, Marine JC, Danovi D, Falini B, Pelicci PG. Nucleophosmin regulates the stability and transcriptional activity of p53. Nat Cell Biol. 2002;4(7):529-33

35. Lee SB, Xuan Nguyen TL, Choi JW, Lee KH, Cho SW, Liu Z, Ye K, Bae SS, Ahn JY. Nuclear Akt interacts with B23/NPM and protects it from proteolytic cleavage, enhancing cell survival. Proc Natl Acad Sci USA. 2008;105(43):16584-9. 
36. Zhang MJ, Ding YL, Xu CW, Yang Y, Lian WX, Zhan YQ, Li W, Xu WX, Yu $M, \mathrm{Ge} C H$, et al. Erythroid differentiation-associated gene interacts with NPM1 (nucleophosmin/B23) and increases its protein stability, resisting cell apoptosis. FEBS J. 2012;279(16):2848-62.

37. Kular RK, Yehiely F, Kotlo KU, Cilensek ZM, Bedi R, Deiss LP. GAGE, an antiapoptotic protein binds and modulates the expression of nucleophosmin/B23 and interferon regulatory factor 1. J Interferon Cytokine Res. 2009;29(10):645-55.

38. Dhar SKSCD. Nucleophosmin blocks mitochondrial localization of p53 and apoptosis. J Biol Chem. 2009;284(24):16409-18.

39. Chattopadhyay A, Hood BL, Conrads TP, Redner RL. Extrinsic apoptosis is impeded by direct binding of the APL fusion protein NPM-RAR to TRADD. Mol Cancer Res. 2014;12(9):1283-91.

40. Leong SM, Tan BX, Bte Ahmad B, Yan T, Chee LY, Ang ST, Tay KG, Koh $L P$, Yeoh AE, Mok YK, Lim TM. Mutant nucleophosmin deregulates cell death and myeloid differentiation through excessive caspase- 6 and -8 inhibition. Blood. 2010;116(17):3286-96.

41. Ceccon M, Merlo ME, Mologni L, Poggio T, Varesio LM, Menotti M, Bombelli S, Rigolio R, Manazza AD, Di Giacomo F, et al. Excess of NPM-ALK oncogenic signaling promotes cellular apoptosis and drug dependency. Oncogene. 2016;35(29):3854-65.

42. Wang W, Budhu A, Forgues M, Wang XW. Temporal and spatial control of nucleophosmin by the Ran-Crm1 complex in centrosome duplication. Nat Cell Biol. 2005;7(8):823-30.

43. Zatsepina OV, Rousselet A, Chan PK, Olson MO, Jordan EG, Bornens M. The nucleolar phosphoprotein $\mathrm{B} 23$ redistributes in part to the spindle poles during mitosis. J Cell Sci. 1999;112(Pt 4):455-66.

44. Amin MA, Matsunaga S, Uchiyama S, Fukui K. Nucleophosmin is required for chromosome congression, proper mitotic spindle formation, and kinetochore-microtubule attachment in HeLa cells. FEBS Lett. 2008;582(27):3839-44.

45. Amin MA, Matsunaga S, Uchiyama S, Fukui K. Depletion of nucleophosmin leads to distortion of nucleolar and nuclear structures in HeLa cells. Biochem J. 2008;415(3):345-51.

46. Ceccaldi R, Rondinelli B, D'Andrea AD. Repair pathway choices and consequences at the double-strand break. Trends Cell Biol. 2016;26(1):52-64.

47. San Filippo J, Sung P, Klein H. Mechanism of eukaryotic homologous recombination. Annu Rev Biochem. 2008:77:229-57.

48. Lee SY, Park JH, Kim S, Park EJ, Yun Y, Kwon J. A proteomics approach for the identification of nucleophosmin and heterogeneous nuclear ribonucleoprotein C1/C2 as chromatin-binding proteins in response to DNA double-strand breaks. Biochem J. 2005:388(Pt 1):7-15.

49. Okuda M, Horn HF, Tarapore P, Tokuyama Y, Smulian AG, Chan PK, Knudsen ES, Hofmann IA, Snyder JD, Bove KE, et al. Nucleophosmin/ B23 is a target of CDK2/cyclin E in centrosome duplication. Cell. 2000:103(1):127-40.

50. Koike A, Nishikawa H, Wu W, Okada Y, Venkitaraman AR, Ohta T. Recruitment of phosphorylated NPM1 to sites of DNA damage through RNF8dependent ubiquitin conjugates. Cancer Res. 2010;70:6746-56.

51. Sekhar KR, Benamar M, Venkateswaran A, Sasi S, Penthala NR, Crooks PA, Hann SR, Geng L, Balusu R, Abbas T, et al. Targeting nucleophosmin 1 represents a rational strategy for radiation sensitization. Int J Radiat Oncol Biol Phys. 2014:89:1106-14.

52. Jansen JG, Tsaalbi-Shtylik A, de Wind N. Roles of mutagenic translesion synthesis in mammalian genome stability, health and disease. DNA Repair. 2015;29:56-64.

53. Ziv O, Zeisel A, Mirlas-Neisberg N, Swain U, Nevo R, Ben-Chetrit N, Martelli MP, Rossi R, Schiesser S, Canman CE, et al. Identification of novel DNA-damage tolerance genes reveals regulation of translesion DNA synthesis by nucleophosmin. Nat Commun. 2014;5:5437.

54. Dijk M, Typas D, Mullenders $L$, Pines A. Insight in the multilevel regulation of NER. Exp Cell Res. 2014:329(1):116-23.

55. Wu MH, Yung BYM. UV stimulation of nucleophosmin/B23 expression is an immediate-early gene response induced by damaged DNA. J Biol Chem. 2002;277:48234-40.

56. Lin CY, Tan BC, Liu H, Shih CJ, Chien KY, Lin CL, Yung BY. Dephosphorylation of nucleophosmin by PP1B facilitates PRB binding and consequent E2F1-dependent DNA repair. Mol Biol Cell. 2010;21(24):4409-17.

57. Krokan HE, Bjoras M. Base excision repair. Cold Spring Harb Perspect Biol. 2013:5(4):a012583.
58. Vascotto C, Fantini D, Romanello M, Cesaratto L, Deganuto M, Leonardi A, Radicella JP, Kelley MR, D'Ambrosio C, Scaloni A, et al. APE1/Ref-1 interacts with NPM1 within nucleoli and plays a role in the rRNA quality control process. Mol Cell Biol. 2009;29:1834-54.

59. Vascotto C, Lirussi L, Poletto M, Tiribelli M, Damiani D, Fabbro D, Damante G, Demple B, Colombo E, Tell G. Functional regulation of the apurinic/apyrimidinic endonuclease 1 by nucleophosmin: impact on tumor biology. Oncogene. 2013;33:1-12

60. Tell G, Fantini D, Quadrifoglio F. Understanding different functions of mammalian AP endonuclease (APE1) as a promising tool for cancer treatment. Cell Mol Life Sci. 2010;67(21):3589-608.

61. Poletto M, Lirussi L, Wilson DM 3rd, Tell G. Nucleophosmin modulates stability, activity, and nucleolar accumulation of base excision repair proteins. Mol Biol Cell. 2014;25(10):1641-52.

62. Londero AP, Orsaria M, Tell G, Marzinotto S, Capodicasa V, Poletto M, Vascotto C, Sacco C, Mariuzzi L. Expression and prognostic significance of APE1/Ref-1 and NPM1 proteins in high-grade ovarian serous cancer. Am J Clin Pathol. 2014;141:404-14.

63. Poletto M, Malfatti MC, Dorjsuren D, Scognamiglio PL, Marasco D, Vascotto C, Jadhav A, Maloney DJ, Wilson DM 3rd, Simeonov A, et al. Inhibitors of the apurinic/apyrimidinic endonuclease 1 (APE1)/nucleophosmin (NPM1) interaction that display anti-tumor properties. Mol Carcinog. 2016;55(5):688-704

64. Morris SW, Kirstein MN, Valentine MB, Dittmer KG, Shapiro DN, Saltman DL, Look AT. Fusion of a kinase gene, ALK, to a nucleolar protein gene, NPM, in non-Hodgkin's lymphoma. Science. 1994:263(5151):1281-4

65. Falini B, Mecucci C, Tiacci E, Alcalay M, Rosati R, Pasqualucci L, La Starza R, Diverio D, Colombo E, Santucci A, et al. Cytoplasmic nucleophosmin in acute myelogenous leukemia with a normal karyotype. N Engl J Med. 2005:352(3):254-66.

66. Vardiman JW, Thiele J, Arber DA, Brunning RD, Borowitz MJ, Porwit A, Harris NL, Le Beau MM, Hellstrom-Lindberg E, Tefferi A, et al. The 2008 revision of the World Health Organization (WHO) classification of myeloid neoplasms and acute leukemia: rationale and important changes. Blood. 2009;114(5):937-51.

67. Falini B, Nicoletti I, Martelli MF, Mecucci C. Acute myeloid leukemia carrying cytoplasmic/mutated nucleophosmin (NPMc+ AML): biologic and clinical features. Blood. 2007;109(3):874-85.

68. Jain P, Kantarjian H, Patel K, Faderl S, Garcia-Manero G, Benjamini O, Borthakur G, Pemmaraju N, Kadia T, Daver N, et al. Mutated NPM1 in patients with acute myeloid leukemia in remission and relapse. Leuk Lymphoma. 2014;55:1337-44.

69. Hirsch P, Qassa G, Marzac C, Tang R, Perrot J-Y, Isnard F, Mohty M, Marie $J P$, Legrand $O$. Acute myeloid leukemia in patients older than 75: prognostic impact of FLT3-ITD and NPM1 mutations. Leuk Lymphoma. 2015:56:147-50

70. Russ AC, Sander S, Lück SC, Lang KM, Bauer M, Rücker FG, Kestler HA, Schlenk RF, Döhner H, Holzmann K, et al. Integrative nucleophosmin mutation-associated microRNA and gene expression pattern analysis identifies novel microRNA — target gene interactions in acute myeloid leukemia. Haematologica. 2011;96:1783-91.

71. Xian J, Shao H, Chen X, Zhang S, Quan J, Zou Q, Jin H, Zhang L. Nucleophosmin mutants promote adhesion, migration and invasion of human leukemia THP-1 cells through MMPs up-regulation via Ras/ERK MAPK signaling. Int J Biol Sci. 2016;12:144-55.

72. Cheng K, Sportoletti P, Ito K, Clohessy JG, Teruya-Feldstein J, Kutok JL, Pandolfi PP. The cytoplasmic NPM mutant induces myeloproliferation in a transgenic mouse model. Blood. 2010;115:3341-5.

73. Vassiliou GS, Cooper JL, Rad R, Li J, Rice S, Uren A, Rad L, Ellis P, Andrews $\mathrm{R}$, Banerjee $\mathrm{R}$, et al. Mutant nucleophosmin and cooperating pathways drive leukemia initiation and progression in mice. Nat Genet. 2011:43:470-5

74. Colombo E, Martinelli P, Zamponi R, Shing DC, Bonetti P, Luzi L, Volorio S, Bernard L, Pruneri G, Alcalay M, et al. Delocalization and destabilization of the Arf tumor suppressor by the leukemia-associated NPM mutant. Cancer Res. 2006;66(6):3044-50.

75. Bonetti P, Davoli T, Sironi C, Amati B, Pelicci PG, Colombo E. Nucleophosmin and its AML-associated mutant regulate c-Myc turnover through Fbw7 gamma. J Cell Biol. 2008;182(1):19-26. 
76. Duyster J, Bai RY, Morris SW. Translocations involving anaplastic lymphoma kinase (ALK). Oncogene. 2001;20(40):5623-37.

77. Redner RL, Rush EA, Faas S, Rudert WA, Corey SJ. The t(5;17) variant of acute promyelocytic leukemia expresses a nucleophosmin-retinoic acid receptor fusion. Blood. 1996;87(3):882-6.

78. Yoneda-Kato N, Look AT, Kirstein MN, Valentine MB, Raimondi SC, Cohen KJ, Carroll AJ, Morris SW. The t(3;5)(q25.1;q34) of myelodysplastic syndrome and acute myeloid leukemia produces a novel fusion gene, NPM-MLF1. Oncogene. 1996;12(2):265-75.

79. Holmberg Olausson K, Elsir T, Moazemi Goudarzi K, Nistér M, Lindström MS. NPM1 histone chaperone is upregulated in glioblastoma to promote cell survival and maintain nucleolar shape. Sci Rep. 2015;5:16495.

80. Coutinho-Camillo CM, Lourenco SV, Nishimoto IN, Kowalski LP, Soares FA. Nucleophosmin, p53, and Ki-67 expression patterns on an oral squamous cell carcinoma tissue microarray. Hum Pathol. 2010;41(8):1079-86

81. Liu X, Liu D, Qian D, Dai J, An Y, Jiang S, Stanley B, Yang J, Wang B, Liu X, et al. Nucleophosmin (NPM1/B23) interacts with activating transcription factor 5 (ATF5) protein and promotes proteasome- and caspasedependent ATF5 degradation in hepatocellular carcinoma cells. J Biol Chem. 2012;287:19599-609.

82. Kim K-H, Yoo BC, Kim WK, Hong JP, Kim K, Song EY, Lee JY, Cho JY, Ku J-L. CD133 and CD133-regulated nucleophosmin linked to 5-fluorouracil susceptibility in human colon cancer cell line SW620. Electrophoresis. 2014;35:522-32

83. Wong JCT, Hasan MR, Rahman M, YU AC, Chan SK, Schaeffer DF, Kennecke HF, Lim HJ, Owen D, Tai IT. Nucleophosmin 1, upregulated in adenomas and cancers of the colon, inhibits p53-mediated cellular senescence. Int J Cancer. 2013;133:1567-77.

84. Liu Y, Zhang F, Zhang X-F, Qi L-S, Yang L, Guo H, Zhang N. Expression of nucleophosmin/NPM1 correlates with migration and invasiveness of colon cancer cells. J Biomed Sci. 2012;19:53.

85. Kalra RS, Bapat SA. Enhanced levels of double-strand DNA break repair proteins protect ovarian cancer cells against genotoxic stress-induced apoptosis. J Ovarian Res. 2013;6:66.

86. Zhou Y, Shen J, Xia L, Wang Y. Estrogen mediated expression of nucleophosmin 1 in human endometrial carcinoma clinical stages through estrogen receptor-a signaling. Cancer cell Int. 2014;14:540.

87. Leotoing L, Meunier L, Manin M, Mauduit C, Decaussin M, Verrijdt G, Claessens F, Benahmed M, Veyssiere G, Morel L, et al. Influence of nucleophosmin/B23 on DNA binding and transcriptional activity of the androgen receptor in prostate cancer cell. Oncogene. 2008:27(20):2858-67.

88. Subong EN, Shue MJ, Epstein Jl, Briggman JV, Chan PK, Partin AW. Monoclonal antibody to prostate cancer nuclear matrix protein (PRO:4216) recognizes nucleophosmin/B23. Prostate. 1999;39(4):298-304.

89. Loubeau G, Boudra R, Maquaire S, Lours-Calet C, Beaudoin C, Verrelle $P$, Morel L. NPM1 silencing reduces tumour growth and MAPK signalling in prostate cancer cells. PLoS One. 2014;9:e96293.

90. Tsui KH, Cheng AJ, Chang P, Pan TL, Yung BY. Association of nucleophosmin/B23 mRNA expression with clinical outcome in patients with bladder carcinoma. Urology. 2004;64(4):839-44.

91. Pianta A, Puppin C, Franzoni A, Fabbro D, Di Loreto C, Bulotta S, Deganuto M, Paron I, Tell G, Puxeddu E, et al. Nucleophosmin is overexpressed in thyroid tumors. Biochem Biophys Res Commun. 2010;397(3):499-504.

92. Pianta A, Puppin C, Passon N, Franzoni A, Romanello M, Tell G, Di Loreto C, Bulotta S, Russo D, Damante G. Nucleophosmin delocalization in thyroid tumour cells. Endocr Pathol. 2011;22:18-23.

93. Leal MF, Mazzotti TKF, Calcagno DQ, Cirilo PDR, Martinez MC, Demachki S, Assumpção PP, Chammas R, Burbano RR, Smith MC. Deregulated expression of nucleophosmin 1 in gastric cancer and its clinicopathological implications. BMC Gastroenterol. 2014;14:9.

94. Karhemo P-R, Rivinoja A, Lundin J, Hyvönen M, Chernenko A, Lammi J Sihto $H$, Lundin $M$, Heikkilä P, Joensuu $H$, et al. An extensive tumor array analysis supports tumor suppressive role for nucleophosmin in breast cancer. Am J Pathol. 2011;179:1004-14.

95. Jian Y, Gao Z, Sun J, Shen Q, Feng F, Jing Y, Yang C. RNA aptamers interfering with nucleophosmin oligomerization induce apoptosis of cancer cells. Oncogene. 2009;28:4201-11.
96. Perera Y, Farina HG, Gil J, Rodriguez A, Benavent F, Castellanos L, Gómez RE, Acevedo BE, Alonso DF, Perea SE. Anticancer peptide CIGB-300 binds to nucleophosmin/B23, impairs its CK2-mediated phosphorylation, and leads to apoptosis through its nucleolar disassembly activity. Mol Cancer Ther. 2009;8:1189-96.

97. Qi W, Shakalya K, Stejskal A, Goldman A, Beeck S, Cooke L, Mahadevan D. NSC348884, a nucleophosmin inhibitor disrupts oligomer formation and induces apoptosis in human cancer cells. Oncogene. 2008:27:4210-20

98. Wulff JE, Siegrist R, Myers AG. The natural product avrainvillamide binds to the oncoprotein nucleophosmin. J Am Chem Soc 2007;129:14444-51

99. Poletto M, Malfatti MC, Dorjsuren D, Scognamiglio PL, Marasco D, Vascotto C, Jadhav A, Maloney DJ, Wilson DM, Simeonov A, et al. Inhibitors of the apurinic/apyrimidinic endonuclease 1 (APE1)/nucleophosmin (NPM1) interaction that display anti-tumor properties. Mol Carcinog 2015; 1:n/a-n/a.

100. Penthala NR, Ketkar A, Sekhar KR, Freeman ML, Eoff RL, Balusu R, Crooks PA. 1-Benzyl-2-methyl-3-indolylmethylene barbituric acid derivatives: anti-cancer agents that target nucleophosmin 1 (NPM1). Bioorg Med Chem. 2015;23:7226-33.

101. Destouches D, Sader M, Terry S, Marchand C, Maille P, Soyeux P, Carpentier G, Semprez F, Ceraline J, Allory Y, et al. Implication of NPM1 phosphorylation and preclinical evaluation of the nucleoprotein antagonist N6L in prostate cancer. Oncotarget. 2016. doi:10.18632/ oncotarget.8043.

102. Luskin MR, Lee JW, Fernandez HF, Abdel-Wahab O, Bennett JM, Ketterling RP, Lazarus HM, Levine RL, Litzow MR, Paietta EM, et al. Benefit of high-dose daunorubicin in AML induction extends across cytogenetic and molecular groups. Blood. 2016;127(2):1551-8.

103. El Hajj H, Dassouki Z, Berthier C, Raffoux E, Ades L, Legrand O, Hleihel R, Sahin U, Tawil N, Salameh A, et al. Retinoic acid and arsenic trioxide trigger degradation of mutated NPM1, resulting in apoptosis of AML cells. Blood. 2015;125:3447-54

104. Martelli MP, Gionfriddo I, Mezzasoma F, Milano F, Pierangeli S, Mulas F, Pacini R, Tabarrini A, Pettirossi V, Rossi R, et al. Arsenic trioxide and alltrans retinoic acid target NPM1 mutant oncoprotein levels and induce apoptosis in NPM1-mutated AML cells. Blood. 2015;125:3455-65.

105. Garcia JS, Huang M, Medeiros BC, Mitchell BS. Selective toxicity of investigational ixazomib for human leukemia cells expressing mutant cytoplasmic NPM1: role of reactive oxygen species. Clin Cancer Res. 2016;22(8):1978-88

106. Huang M, Thomas D, Li MX, Feng W, Chan SM, Majeti R, Mitchell BS. Role of cysteine 288 in nucleophosmin cytoplasmic mutations: sensitization to toxicity induced by arsenic trioxide and bortezomib. Leukemia. 2013;27:1970-80.

107. Negrini S, Gorgoulis VG, Halazonetis TD. Genomic instability—an evolving hallmark of cancer. Nat Rev Mol Cell Biol. 2010;11(3):220-8.

108. Liu Y, He P, Liu F, Shi L, Zhu H, Zhao J, Wang Y, Cheng X, Zhang M. Prognostic significance of NPM1 mutations in acute myeloid leukemia: a meta-analysis. Mol Clin Oncol. 2014;2(2):275-81.

\section{Submit your next manuscript to BioMed Central and we will help you at every step:}

- We accept pre-submission inquiries

- Our selector tool helps you to find the most relevant journal

- We provide round the clock customer support

- Convenient online submission

- Thorough peer review

- Inclusion in PubMed and all major indexing services

- Maximum visibility for your research

Submit your manuscript at www.biomedcentral.com/submit 